\title{
Deciphering the disease-related molecular networks using urine proteomics
}

\author{
Paulo André Dias Bastos a, Antonia Vlahou ${ }^{\text {b, c }}$, Adelino Leite-Moreira ${ }^{\text {d }}$, \\ Lúcio Lara Santos ${ }^{\text {e, }}$, Rita Ferreira ${ }^{g}$, Rui Vitorino ${ }^{\text {a, }}{ }^{\text {, * }}$ \\ a Department of Medical Sciences, Institute for Biomedicine - iBiMED, University of Aveiro, Aveiro, Portugal \\ ${ }^{\mathrm{b}}$ Biomedical Research Foundation, Academy of Athens, Athens, Greece \\ ${ }^{c}$ Center of Systems Biology, Biomedical Research Foundation Academy of Athens, Athens, Greece \\ ${ }^{\mathrm{d}}$ Departmento de Cirurgia e Fisiologia, Faculdade de Medicina, Unidade de Investigação Cardiovascular, Universidade do Porto, Porto, Portugal \\ e Experimental Pathology and Therapeutics Group - Research Center, Portuguese Oncology Institute - Porto (IPO-Porto), Porto, Portugal \\ ${ }^{\mathrm{f}}$ Department of Surgical Oncology, Portuguese Oncology Institute - Porto (IPO-Porto), Porto, Portugal \\ ${ }^{\mathrm{g}}$ Mass Spectrometry Group, QOPNA, Department of Chemistry, University of Aveiro, Aveiro, Portugal
}

\section{A R T I C L E I N F O}

Article history:

Available online 22 July 2017

\section{Keywords:}

Protein profiling

Bioinformatics

Cancer

Cardiovascular diseases

Autoimmune

Inflammation

\begin{abstract}
A B S T R A C T
Despite the large number of studies focused on the impact of diseases on urine proteome, few outputs with clinical meaning were retrieved so far. The goal of this study was to identify the biological processes modulated in urine by distinct diseases to better understand disease pathogenesis and to identify urinary proteins with potential diagnosis value. We searched PubMed and SCOPUS databases for mass spectrometry-based experimental papers and pooled differentially expressed proteins by disease and target organic system.

A total of 2572 differentially expressed proteins or peptides were pooled from 89 studies focused on 57 diseases. Data analysis highlighted inflammation as a biological process modulated by all diseases. However, specific inflammatory signatures are associated with specific diseases and/or aetiologies. Moreover, specific biological processes were identified for specific groups of pathologies and unique proteins identified. Overall, integrative data analysis from urine proteomics/peptidomics reinforces the clinical potential of this body fluid for the clinical management of distinct diseases.
\end{abstract}

() 2017 Elsevier B.V. All rights reserved.

\section{Introduction}

Proteomics-based studies offer the possibility of studying disease-specific associated proteins and their deregulation without prior knowledge thereof $[1,2]$. These proteins can be seen as potential biomarkers of a physiological or pathological process or the reflection of a therapeutic response [3]. However, the journey of a biomarker from the bench to the clinics is long and challenging [4]. One of the challenges relies on the choice of the biological sample, considering not only methodological but also patients' features. The screening of disease biomarkers in tissues has been a valuable tool in both clinical practice and research settings, but the invasiveness of the sampling procedure and sample complexity make

\footnotetext{
* Corresponding author. Department of Medical Sciences, University of Aveiro, 3810-193 Aveiro, Portugal.

E-mail address: rvitorino@ua.pt (R. Vitorino).
}

this biological sample inappropriate for monitoring purposes. Therefore, biological fluids are preferred over tissue specimens whenever possible. Blood derived samples have been chosen for laboratorial studies, both clinical and research ones, because blood is in direct contact with most cells in the body and it is relatively easy to collect. However, this first feature also makes it an extremely complex fluid [5]. Alternatively, urine has become one of the most attractive diagnostic samples due to the non-invasiveness of its collection, unrestricted quantities obtainable, stability, possibility of being repeatedly sampled, and lower complexity compared to other fluids as blood plasma or serum [6].

Despite all the advances in urine proteomics, few protein targets are monitored in urine for clinical decision, being albumin considered the most reliable marker in diseases such as diabetesrelated nephropathy and heart failure [7-10]. However, there is considerable hope in the technological advances observed in the last years to bring novel urine biomarkers into clinical practice [11]. Thus, this review aims to provide an integrative picture of the main 
molecular pathways modulated in urine by various diseases including cancer, infections and cardiovascular diseases. Data mining was used to provide novel insights on disease pathogenesis and to disclose potential urinary biomarkers.

\section{Methodological issues in urine proteome analysis}

A human being daily excretes less than $150 \mathrm{mg}$ of proteins in urine, influenced mainly by protein concentration in blood and glomerular filtration, and partially by phenomena such as tubular reabsorption, secretion, and degradation $[12,13]$. About $70 \%$ of urinary proteins are of kidney origin, and only about 30\% come from plasma [14]. The most abundant soluble protein in urine is Tamm-Horsfall protein (also known as uromodulin), though certain disease conditions can also greatly increase the concentration of albumin and other proteins, such as immunoglobulins [15]. Notwithstanding the informative value of these and other highly abundant urinary proteins, they might hamper the analysis of other smaller and less abundant proteins. Its high salt content, mainly in urea, also influences the analysis of urine proteome [16]. As a result, urine samples are usually fractionated before protein profiling in order to remove salts and, eventually, the more abundant proteins to increase sensibility for smaller and less abundant proteins with potential diagnostic value (reviewed by Refs. [17,18]).

The urinary proteome may be significantly affected by normal physiologic variations, including circadian ones, and environmental factors. Sample timing and subjects' hydration status must therefore be considered in data interpretation, and $24 \mathrm{~h}$ urine samples should be preferred to spot urine samples. However, to the best of our knowledge, only 3 studies have analyzed $24 \mathrm{~h}$ urine samples [19-21]. Most frequently, urine collection consists of spontaneously voided samples, usually the midstream portion of second morning urines in order to avoid contaminations by urinary tract overnight residues. In the majority of proteomic studies, urine samples were collected either during multiple days (less frequently) or at multiple time points during a limited time period (e.g. $24 \mathrm{~h}$, pre-/peri-/post-operative) after an acute event. Urine samples obtained from indwelling or foley catheters are scarce for practical reasons, as do biopsied samples [22,23].

After collection, a protease inhibitor can be added if samples are not immediately analyzed, and/or samples should be frozen. By adding protease inhibitors, samples can be used to either proteomics or peptidomics studies, being subsequently hydrolyzed in the former case or left intact in the later one [24]. However, proteases inhibitors have been proven ineffective in increasing protein identification and in reducing trypsin digestion efficacy. In most studies, urine samples are centrifuged, and if not immediately analyzed, frozen at $-80^{\circ} \mathrm{C}[11,25]$. Once proteins can precipitate during the freezing process, samples should be fully resolubilized when thawed. Sonication, addition of detergents or Tris buffers are typically preferred in the resolubilization procedure [25].

Urine samples are usually subjected to fractionation, prefractionation, and pre-concentration to simplify downstream analytical procedures or to make possible the analysis of subproteomes (e.g. proteins within a molecular weight range) [19,26-33]. Several methods have been used to concentrate and desalt proteins, including dialysis, protein precipitation, and lyophilization, whose advantages and limitations were discussed by others $[34,35]$. Additional methods can be employed to remove the highly abundant proteins (e.g. albumin, uromodulin). These include targeting specific solute compartments such as urinary exosomes [36], and affinity fractionation strategies based on immunodepletion or functionalized beads [37]. The latter technique is based on millions of random hexapeptide ligands [38], whereas immunodepletion is based on depletion of only 6 to 10 , at most, highly abundant proteins [39]. In the characterization of urine proteome/peptidome the most popular approaches are reliant on mass spectrometry (MS), whose approaches are overviewed at Supplementary Table S1.

Despite advances in MS-based technology, we are now facing the problem of standardization of, for instance, methodologies, results reporting, and definition of reference values. A new subset of questions arises, such as what would be the best approach, if there is one, and what do differential expression values of a given protein mean for each person in a clinical perspective.

\section{Data mining}

In order to improve the diagnosis value of urine proteome, a comparative analysis of urine protein profile across several pathophysiological conditions was performed. Data research was carried out from November 2015 to January 2016. We searched PubMed and SCOPUS databases for articles published in the last 10 years, focused on differentially expressed proteins (DEPs) in urine collected from diseased and healthy human subjects. As inclusion criteria, studies had to employ mass spectrometry-based techniques and only statistically significant DEPs (whenever information regarding so was available) were considered. At the end, data from 89 articles was pooled. For detailed information see Supplementary Information 1.

\section{Insights on the functional meaning of urine proteome}

The study of urinary proteome already resulted in the identification of 4783 distinct proteins in healthy conditions (listed at Supplementary Table S3 and retrieved from Refs. [40,41]). The characterization of exosomes contributed in 33\% to urine proteome (Supplementary Table S4). Proteins differentially expressed in 57 pathophysiological conditions were pooled together from the analysis of 89 studies (Supplementary Table S2 and Table S5) which resulted in a list of 2572 DEPs. We considered the DEPs defined in each selected paper despite not being consensual among different studies, once it was adjusted to the methodological approach used and the number of patients included in each study. Most of these studies were focused on renal diseases (23 papers), resulting in the identification of 1054 DEPs, which represents $41 \%$ of total DEPs modulated in urine by diseases. Within renal diseases, the conditions with the largest number of DEPs identified are chronic kidney disease (273 DEPs), nephrotic syndrome (186 DEPs) and IgA nephropathy (183 DEPs). Bladder cancer has also been extensively studied, with eleven studies dedicated to it and 229 DEPs identified. Still, diseases affecting almost all organic systems, excluding the integumentary system, have been studied using urinary proteomics/peptidomics. The analysis of protein frequency across all diseases highlighted three proteins significantly modulated by most of diseases. Fibrillar forming collagen (COL1A1) was upregulated in 16 pathological conditions, collagen alpha-1 (III) (COL3A1) in 12, and alpha-1-antitrypsin in 19 diseases (Supplementary Table S5). These three proteins are known to provide strength and support to many tissues in the body, regulate cell adhesion and motility, promote cell survival and protect tissues from proteolytic degradation by inflammatory cells [42-44].

Our integrative analysis of urine proteome also showed that approximately $85 \%$ of the reported disease-related DEPs were not specific of a single disease. From the remaining, $15 \%$ were specific of a disease and $61 \%$ were part of the normal urine proteome, being either up- or downregulated. Still, 39\% were exclusively detected in the urine during diseased states. Proteins uniquely modulated by a particular group of diseases (e.g. cardiovascular diseases, infectious diseases) are presented in Supplementary Table S5 and represent 
the best candidate biomarkers for distinguishing diseases. This list includes 285 exclusive putative urinary biomarkers (Supplementary Table S6). In contrast to these disease-specific DEPs, proteins involved in immune response were found overrepresented in the urine of patients with distinct diseases regardless the tissue of origin. Nevertheless, distinct inflammatory signatures characterize each unique group of diseases (e.g. cancer, infectious and autoimmune diseases), as highlighted in Fig. 1. For instance, it has been long established that chronic inflammation can induce tumor development, progression and metastatic dissemination, and the development of cells resistant to treatment [45]. However, inflammatory mediators can also activate antigen-presenting cells and promote antigen-mediated tumor repression, and the human host has several mechanisms to perceive and eliminate malignant cells [46]. In infectious diseases, macrophages and other phagocytes are recruited to eliminate the invading microorganism. However, this inflammatory response can be mediated by several noxious agents that also cause tissue damage [47].

To better elucidate this disease-specific immune signature, a functional analysis considering only the immune response mediators was performed. Data showed that while these mediators in cancer were primarily involved in the regulation of complement activation, those of autoimmune diseases were associated to the positive regulation of $\mathrm{T}$ cell mediated cytotoxicity and antigen processing and presentation of exogenous peptide antigen via MHC class I, whereas infectious diseases were found to be significantly associated to deregulations in macrophage activation, regulation of natural killer (NK) cell activation, and antigen processing and presentation of exogenous peptide antigen via MHC class I.

The role of complement in cancer is paradoxal at first sight. Our natural organic defenses are known to fight cancer by promoting a pro-inflammatory state comprising increased complement activation, which is demonstrated by antibody-initiated complementdependent cytolysis and antibody-dependent cell-mediated cytolysis [48]. Paradoxically, complement C3 activation can promote tumor growth, while complement $\mathrm{C} 5$ a receptor signaling pathway activation enhances infiltration by myeloid-derived suppressor cells [49]. However, it is increasingly recognized that the role of the complement system goes beyond hemostasis, with chronic lowgrade activation allowing the complement system to function as a "sonar or radar system" [50,51]. Autoimmune diseases are supposed to be initiated by the activation of antigen specific $T$ cells. Then, T cells activate self-reactive B cells and macrophages, leading to harmful autoantibody responses and direct tissue damage [52]. T cells proliferation is mediated by the recognition of self-MHC/ peptide ligands. While this recognition is required for T cells survival, it leads to strong proliferation under lymphopenic conditions $[53,54]$. Therefore, apart from the dependence on genetic factors, previous exposure to peptide ligands and conditions leading to lymphopenia seem to be triggers of autoimmune diseases [55,56]. In infectious diseases, activated NK cells infiltrate infected tissues [57]. NK cells in lymphoid tissues are activated by dendritic cells [58], but infected cells may upregulate the cell-surface expression of MHC class I molecules and evade NK cell-mediated killing [59]. During infection, circulating monocytes are recruited to local tissues, where they change phenotype and convert into macrophages, recognize and phagocyte pathogens, and adopt an inflammatory state that promotes tissue repair [60]. Though not surprising that distinct groups of diseases induce different inflammatory/immune responses, it is remarkable that the specificity of such inflammatory response in each of these groups of diseases can be accurately monitored by urine protein profiling.

Multiple tissues seem to contribute to urine protein profile in pathological conditions, suggesting that proteins upregulated in distinct organs can pass throughout the blood circulation and the urinary tract to take part in urine composition. In an attempt to map urinary proteins to its tissue of origin, a HeatMap was created. This comparative analysis was based on the match between identified DEPs and protein databases from human tissues obtained from either live or postmortem samples [61]. Then, those proteins that could be precisely mapped to 1 to 3 organs were manually curated and a list of approximately 100 proteins was created

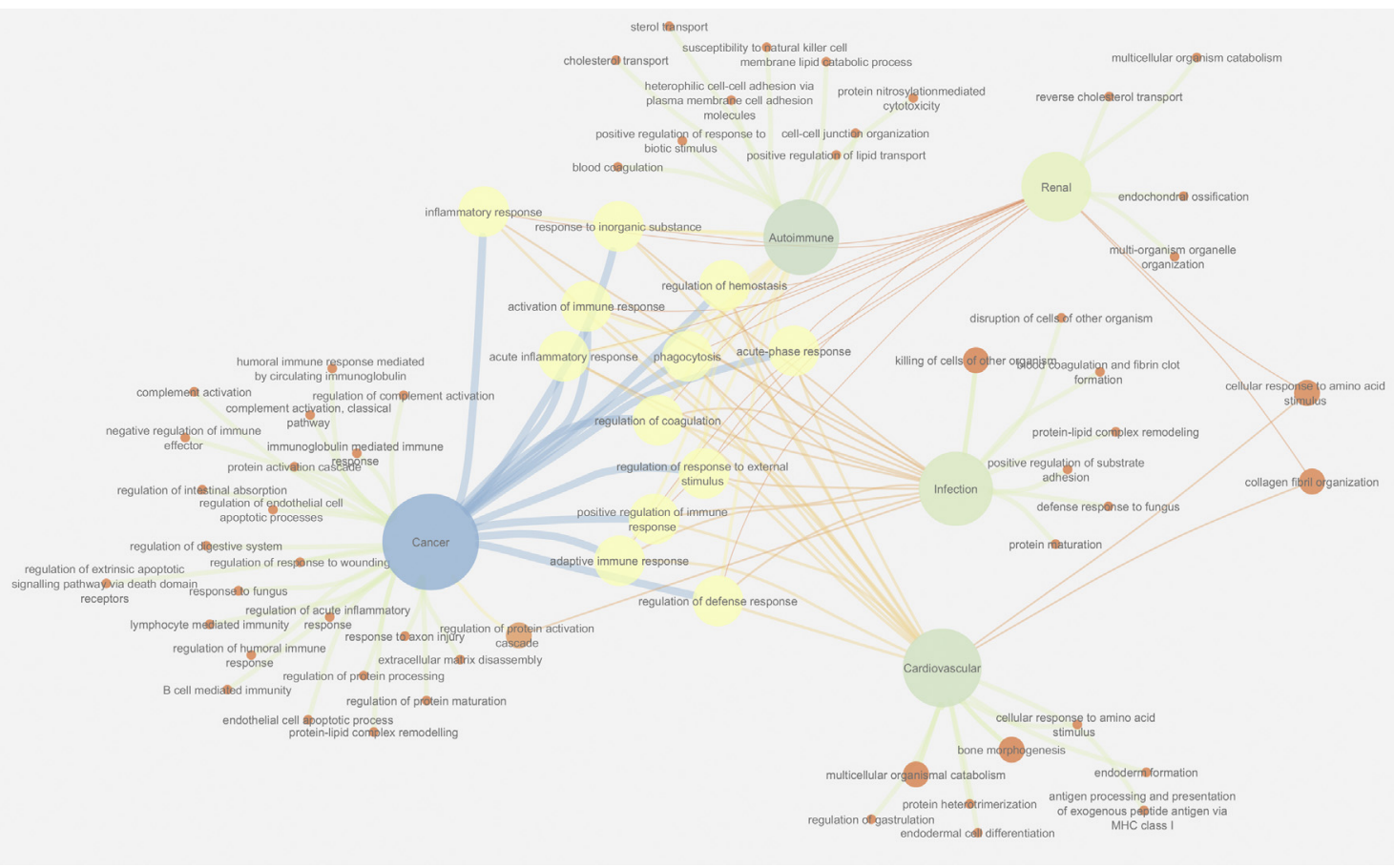

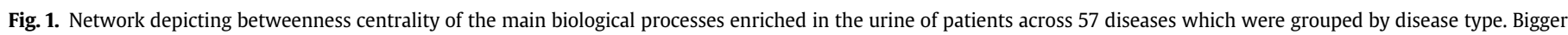
nodes and larger edges correspond to larger capacity, influence, frequency and connectivity. 
(Supplementary Fig. S1 and Table S7). Many of these proteins are of fetal origin, which means that they are expressed at least 10 -fold higher in fetal samples as compared to adult tissues and cells [61]. Several diseases seem to be accompanied by increased expression of fetal genes, most likely in an attempt to recover from tissue damage, to promote cellular growth and division, and to adapt the organism to new requirements. Despite being normally silenced during the adult life, a genome-wide demethylation of fetal genes accounts for phenotype reprogramming under special circumstances, as those of malignant diseases [62,63]. Therefore, methylation-directed studies could be a promising avenue of research targeting the inhibition of fetal genes to avoid rapid and excessive cell proliferation.

To better explore the potential diagnosis value of urinary proteome, an integrative analysis of proteome data per group of diseases was performed, with emphasis in infectious diseases, cancer, autoimmune diseases, cardiovascular and renal diseases.

\subsection{Infectious diseases}

Tuberculosis, sepsis, hepatitis E virus, Klebsiella pneumonia, uropathogenic Escherichia coli, necrotizing enterocolitis, and Histoplasma capsulatum infections modulate the urine protein profile in a unique manner (Supplementary Table S5). For example, while the urine profile of patients infected with K. pneumonia is characterized by the prevalence of human proteins involved in "proteinlipid complex remodeling", "protein maturation", and "regulation of protein activation cascade", the urine of patients infected with $E$. coli is rich in proteins from "blood coagulation and fibrin clot formation", "positive regulation of substrate adhesion" and "killing of cells of other organism". Though E. coli is the most commonly isolated uropathogen [64], K. pneumonia is an opportunistic bacteria responsible for many hospital-acquired urinary tract infections, pneumonia, septicemias and soft tissue infections [65]. Urinary proteins characteristic of $K$. pneumonia infection target erythrocyte and include hemoglobin subunits alpha and delta, band 3 anion transport protein and erythrocyte band 7 integral membrane protein (STOM) (Supplemental Table S5). Unlike E. coli, $K$. pneumonia is surrounded by a capsule, which increases its virulence and allows it to evade the host's immune system. As a result, infections by $K$. pneumonia may not be characterized by a cellular response as strong as the observed in infections by $E$. coli $[66,67]$. The capsular antigens are composed of complex acidic polysaccharides often made up of uronic acids, which limits bacteria opsonisation by complement $\mathrm{C} 3$, thus diminishing its phagocytosis by macrophages and contributing to the upregulation of "protein activation cascade" mediators observed in urine [67].

The bioinformatics analysis of urinary proteins modulated in human host by E. coli support the notion that uropathogenic E. coli invades the urinary tract through human host-derived factors. In this process, macrophages are involved through the activity of chitotriosidase [68] and neutrophil cytosol factors 1B, 2 and 4, which were identified in the urine of infected patients. These factors are either components of the multicomponent enzyme system NADPH-oxidase, responsible for the oxidative burst responsible for reactive oxygen species production, or involved in processing and presentation of exogenous peptide antigen via MHC class I and phagosome maturation, [68-70]. Adhesion molecules are important virulence factors contributing for $E$. coli pathogenicity [71]. While all $E$. coli strains express a wide variety of adhesion factors, uropathogenic $E$. coli isolates express variants of these factors enhancing its affinity for monomannose residues and conferring it a higher tropism towards glycoprotein receptors, extensively expressed by uroepithelial cell, thereby enhancing colonization and infections of the urinary tract [72]. Unlike what observed in infections with $K$. pneumoniae, the opsonisation of $E$. coli with complement factor C3 promotes its internalization by renal tubular epithelial cells through its interaction with the complement receptor CR1-related protein, enhancing its ability to colonize and invade the kidney [73]. Fig. 2 overviews the urinary proteins uniquely modulated by these and others infectious diseases.

\subsection{Cancer}

Each type of cancer (prostate, uterus, bladder, colon, ovarian, and renal cell) seems to present a unique set of urinary protein markers (Supplementary Table S5). Together, these proteins are involved in the "regulation of digestive system processes", "regulation of intestinal absorption", "response to axon injury", "regulation of extrinsic apoptotic signaling pathway via death domain receptors", "endothelial cell apoptotic process", and "regulation of endothelial cell apoptotic processes" (Fig. 1), reflecting in part the deregulation of affected organs but also tumor-specific processes, namely alterations in apoptotic signaling pathways and neovascularization. In fact, impairment of the apoptotic signaling process is one hallmark of cancer, resulting from the accumulation of genetic defects and leading to aberrant cellular proliferation, tumorigenesis, neovascularization and drug resistance $[74,75]$. Despite the low number of proteins modulated by colon cancer, when considering all proteins modulated by cancer it was noticed an overrepresentation of the "regulation of digestive system" process.

While renal cell carcinoma is characterized by a set of proteins involved mainly in "extracellular matrix disassembly", a set of proteins responsible for "protein activation cascade", "regulation of response to wounding", "protein-lipid complex remodelling", "response to fungus", and "negative regulation of immune effector" characterizes bladder cancer. In addition to the tissue remodeling caused by tumorigenesis, extracellular matrix components, especially integrins, are known to modulate cellular responses to apoptotic stimuli [76]. These extracellular matrix-dependent modulation of the apoptotic process also promotes the epithelialmesenchymal transition, being responsible, at least in part for organ morphogenesis, tissue remodeling, embryonic development, metastasis and wound healing [77,78], all of which were monitored by urine protein profiling. In the urine of patients with bladder cancer several apolipoproteins isoforms were found upregulated, which contributed to the overrepresentation of "protein-lipid complex remodelling" process. Still, the upregulation of apolipoproteins is not specific of bladder cancer unlike DNA-(apurinic or pyrimidinic site) lyase (APEX1), which was found exclusively upregulated in the urine of patients with bladder cancer. This enzyme functions as an apurinic/apyrimidinic (AP) endonuclease in the DNA base excision repair pathway of DNA lesions induced by oxidative and alkylating agents [79]. Its study in the setting of bladder cancer has been mainly focused on risk-associated polymorphisms [80] but our data analysis suggests that high urinary levels might be seen as a marker of bladder cancer. In the set of prostate cancer, the aberrant expression of proteins like ERG and vinculin was detected through urine proteomics. ERG is a transcriptional factor overexpressed in $50 \%$ of human prostate cancers [81], and vinculin overexpression seems to contribute to prostate cancer progression by enhancing tumor cell proliferation [82].

Fig. 2 overviews the urinary proteins uniquely modulated by different types of cancer.

\subsection{Autoimmune diseases}

The biological processes more represented in the urine of patients with rheumatoid arthritis (RA), Kawasaki disease, Systemic Lupus Erythematous, Type 1 Diabetes mellitus and Transplant 


\begin{tabular}{|l}
\hline CANCER \\
\hline $\begin{array}{l}\text { Prostate } \\
\text { VCL; EGR; SARDH }\end{array}$ \\
\hline Renal cell \\
RABGAP1 \\
\hline Uterus \\
NEB \\
\hline Bladder \\
GOT2; ACOX1; AEBP1 \\
AKR1C2; APEX1;APMAP \\
BCAP31; TGFB1; C1QA \\
C1QB; C1QC \\
\hline
\end{tabular}

\begin{tabular}{|l|}
\hline AUTOIMMUNE DISEASES \\
\hline $\begin{array}{l}\text { Rheumatoid arthritis } \\
\text { CFHR1; COLTL1; CTSA } \\
\text { PRSS1 }\end{array}$ \\
\hline $\begin{array}{l}\text { Systemic Lupus } \\
\text { erythematosus } \\
\text { HAMP }\end{array}$ \\
\hline $\begin{array}{l}\text { Transplant rejection } \\
\text { KLK3; HLA-DRA; IGFBP2 } \\
\text { HBE1 }\end{array}$ \\
\hline $\begin{array}{c}\text { Kawasaki disease } \\
124 \text { unique proteins }\end{array}$ \\
\hline Type 1 diabetes \\
52 unique proteins \\
\hline
\end{tabular}

\begin{tabular}{|l|}
\hline CARDIOVSCULAR DISEASES \\
\hline Kawasaki disease \\
124 unique proteins \\
\hline preeclampsia \\
HSPD1; VCP \\
\hline LV diastolic \\
dysfunction \\
CRIP1; DENND4A;DSEL \\
HNRNPAB;IGFN1;ITGA6 \\
KMT2D;MTA2;OSBP2 \\
PLA1A;TUFB;WBP11 \\
WHAB;YWHAE;ZBTB46 \\
ZNF853;AP3B1;BMP5 \\
CC2D1B;COL13A1; \\
COL1A1;COL26A1; \\
COL5A2;COL6A2 \\
\hline
\end{tabular}

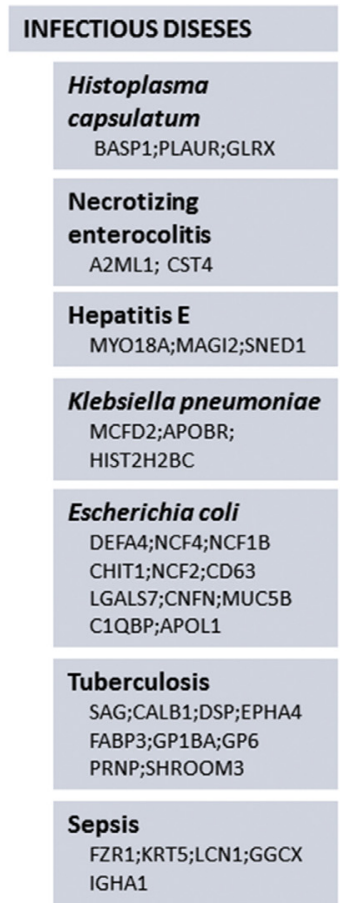

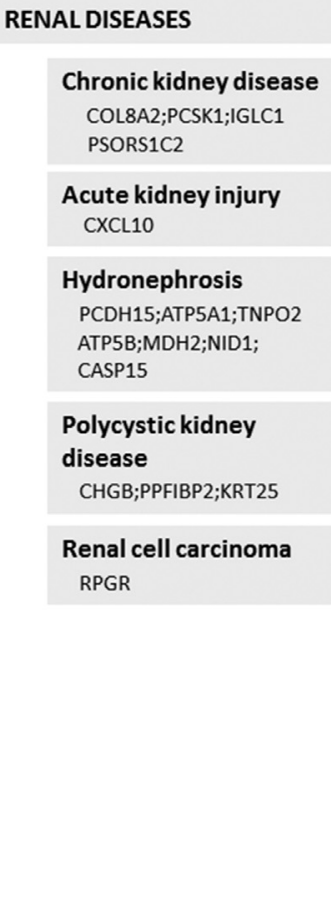

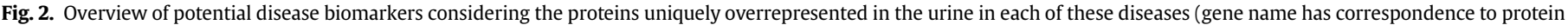
name at Supplementary Table S5).

Rejections are "cholesterol transport", "positive regulation of lipid transport", "sterol transport", “cell-cell junction organization”, and "blood coagulation" (Fig. 1). The increase in cholesterol transport most likely reflects an increase in lipid inflammatory mediators, which are known to trigger and mediate human diseases with an autoimmune component [83]. The upregulation of the biological process "cell-cell junction organization" is most likely due to proteins such as cell adhesion molecule 1 (CADM1) and cadherins 11 (CDH11), 13 (CDH13) and 17 (CDH17).

Looking to specific autoimmune diseases, it was noticed a high prevalence of the biological processes "protein nitrosylation", "susceptibility to natural killer cell mediated cytotoxicity", "positive regulation of response to biotic stimulus", and "heterophilic cell-cell adhesion via plasma membrane cell adhesion molecules" in RA. The list of proteins involved in these biological processes is long and diverse (Supplementary Table S5); however, data analysis highlighted four proteins uniquely upregulated in the urine of RA patients, specifically complement factor $\mathrm{H}$ related protein 1 (CFHR1), coactosin-like protein (COLTL1), lysosomal protective protein (CTSA) and trypsin-1 (PRSS1). Despite no clear association of trypsin-1 to RA, the other three proteins seem related to the inflammatory response that characterizes this autoimmune disease. CFHR1 has a role in the complement regulation [84]. COLTL1 supports 5-lipoxygenase activity in leukotrienes, lipoxins and resolvin E1 biosynthesis, key lipid inflammatory mediators [85]. CTSA is a protective protein essential for both the activity of $\beta$ galactosidase and neuraminidase [86]. Indeed, the loss of sugars as galactose seems associated with this pathology [87].

The autoimmune diseases with more unique urinary proteins identified are Kawasaki disease and type 1 Diabetes mellitus. Among the biological processes regulated by Kawasaki disease are "antigen processing and presentation of exogenous peptide antigen via MHC class I", "signal transduction involved in cell cycle checkpoint", "regulation of calcium ion transport into cytosol", "detection of external biotic stimulus", and "regulation of protein depolymerization". These processes were found to be mediated by 124 proteins exclusively overrepresented in Kawasaki disease (Supplemental Table S5), as for example regulator complex protein LAMTOR1, P2X purinoceptor 4 and 60S ribosomal protein L22. LAMTOR1 is involved in cell cycle arrest, endosome localization and organization and macroautophagy [88], and because it is part of lysosomes and late endosomes membranes, it can also be found in extracellular exosomes [89]. 60S ribosomal protein L22 is a structural constituent of ribosome responsible for alpha-beta $\mathrm{T}$ cell differentiation and SRP-dependent cotranslational protein targeting to membrane [90] Therefore, Kawasaki disease is significantly characterized by alterations in cell growth and cell cycle, apoptosis and proliferation-associated fundamental processes such as endothelial cell activation response to growth factors. These processes might be triggered by the inflammatory response that characterizes Kawasaki disease.

Type 1 Diabetes is characterized by proteins involved in "reverse cholesterol transport" and "triglyceride catabolic process". Indeed, the association between type 1 Diabetes and dyslipidemia was already reported for young patients [91]. The urine protein profile of patients with type 1 Diabetes was found to be significantly different than those of patients with type 2 Diabetes (Supplementary Table S5). In fact, only $4 \%$ of the whole set of DEPs were common to both groups of patients. Overall, the main biological processes modulated by both types of Diabetes mellitus are rather unspecific, reflecting mainly the systemic alterations that characterize diabetes. However, in contrast with type 1 Diabetes, type 2 Diabetes is characterized by an "acute inflammatory response" and "deregulation in vitamin transport" and "digestive system processes", for which contributed apolipoproteins, retinol binding protein 4 and SERPINA3.

Fig. 2 overviews the urinary proteins exclusively modulated by autoimmune diseases.

\subsection{Cardiovascular diseases}

In this group of diseases that includes chronic heart failure, coronary artery disease, left ventricle diastolic dysfunction, 
Kawasaki disease, preeclampsia and vasculitis, the biological processes more represented in the urine were "multicellular organismal catabolism", "bone morphogenesis" and "cellular response to amino acid stimulus". It was noticed the upregulation of collagen synthesis, degradation and deposition, which resulted in several distinct collagen fragments. Despite being primarily correlated with fibrosis, many of the identified collagens are also involved in cell differentiation and angiogenesis [92]. Several other proteins contributed for these biological processes, including copine-9, copine-7, osteopontin, bone morphogenetic protein (BMP) 5, and WW domainbinding protein 11. Among these, BMPs have been attributed an important role in cardiovascular diseases. Multiple BMPs-dependent events, which work in concert to attain normal cardiovascular development, control collagen remodeling and cellular proliferation, illustrating the tight connection between collagens, BMPs and the development and homeostasis of the heart [93-95]. In addition to BMPs, its receptors are also crucial for heart and vascular homeostasis. Diminished expression levels were reported in pulmonary arterial hypertension and its absence was shown to be lethal [96].

Significantly distinct biological processes were identified for two cardiovascular diseases: Kawasaki disease, which was already discussed in the setting of autoimmune diseases, and left ventricle diastolic dysfunction. In this disease a significant enrichment of the "endodermal cell differentiation", "endoderm formation”, “collagen fibril organization", and "regulation of gastrulation" processes was observed. These findings highlight a high fibrotic state and the need for neovascularization in left ventricle diastolic dysfunction. The turnover of collagen fibers is mediated by fibroblasts and myofibroblasts in response to mechanical stress, vasoactive peptides and growth factors, and pro-inflammatory cytokines such as TNF- $\alpha$ and IL-6 [97]. The differentiation of fibroblasts into myofibroblasts is responsible for the synthesis and degradation of collagens I and III in the heart [97], a process that must account for the observed enrichment in differentiation and gastrulation-associated mediators in urine samples from patients with left ventricle diastolic dysfunction. Therefore, urine profiling reflects not only alterations in the balance of collagen synthesis/degradation, but also the main processes responsible for and resulting from alterations in this balance. Increased collagen synthesis over degradation results in the accumulation of collagen fibers, myocardial fibrosis, ventricular hypertrophy and diastolic dysfunction [98].

\subsection{Renal diseases}

Most studies based on urinary proteomics and peptidomics are focused on renal and urinary track diseases (Supplemental Table S4). The comparison of proteome data among distinct renal diseases highlighted a great overlap, involving "cellular response to amino acid stimulus", "collagen fibril organization", "endochondral ossification", "multicellular organism catabolism", and "reverse cholesterol transport" (Fig. 1). A link between renal and cardiovascular diseases could thus be established, once both groups of diseases are significantly associated with BMPs and collagen deposition/degradation. Disorders affecting the cardiovascular or renal systems will most likely involve the other system, giving rise to a pathological condition called cardiorenal syndrome $[99,100]$. For instance, it is possible that BMPs involved in one of these two groups of diseases end up also affecting the other one, and this interaction may result in one disease leading to the other or both diseases developing simultaneously. Alternatively, some "protective" BMPs might be increased in order to attenuate common consequences of cardiovascular and renal diseases. Renal diseases appear to be associated with increased excretion of collagen fibers [101], but the profile of deregulated collagens seems to differ between the two groups of diseases (Supplementary Table S5).

\subsection{Diseases of the digestive system}

With the exception of Crohn's disease, which was represented only by three unspecific proteins and was thus not amenable to bioinformatics analysis, all diseases somehow affecting organs of the digestive system were associated with unique urinary proteins (Supplementary Table S5). Hepatitis E and necrotizing enterocolitis, despite being both disease of infectious etiology, are discussed in this section due to their target organs and clinical presentations. Hepatitis E is characterized by "retina homeostasis", while necrotizing enterocolitis is characterized almost exclusively by "positive regulation of peptide secretion". Proteins deregulated in Hepatitis E included membrane-associated guanylate kinase, WW and PDZ domain-containing protein 2 (MAGI2), prostaglandin-H2 D-isomerase and zinc-alpha-2-glycoprotein. MAGI2 is located at synaptosomes and is involved in cellular responses to nerve growth factor stimuli, regulating mitotic cell cycle arrest, cell migration and proliferation, neuroligin clustering for postsynaptic membrane assembly and neuronal development [102-104]. Other PDZ proteins have already been reported as involved in viral infections. For instance, the PDZ protein PDZK1 facilitates hepatitis C virus entry into hepatocytes, resulting in hepatic fibrosis or cirrhosis, while the PDZ protein PDZD8 is known to suppress herpes simplex virus 1 replication $[105,106]$. In addition, human adenovirus E4-ORF1 and papillomavirus E6 proteins bind to human PDZ domains, including some members of the membrane-associated guanylate kinase (MAGUK) protein family, disrupting cellular tight junctions and promoting malignancy $[107,108]$. So, MAGI2 in urine might to be seen as a marker of hepatitis $E$ infection.

The involvement of "positive regulation of peptide secretion" in necrotizing enterocolitis results from increased endopeptidase and proteolysis activities due to proteins as alpha-2-macroglobulin-like protein 1, cystatin-S, pigment epithelium-derived factor and CD14. For instance, cystatin-S is involved in the negative regulation of endopeptidase activity and proteolysis [109], and its increase must reflect an attempt to mitigate the deleterious effects of exacerbated proteolysis.

In contrast, pancreatitis was characterized by the upregulation of "inflammatory process", "platelet degranulation", and "positive regulation of immune effector process". Proteins that distinguish pancreatitis from the remaining digestive system diseases include poliovirus receptor, which mediates NK cells adhesion with formation of a mature immunological synapse between NK and target cells. This protein triggers the secretion of lytic granules and IFNgamma [110]. V-set and immunoglobulin domain-containing protein 4 was found increased only in the urine of patients with pancreatitis. This protein functions as a phagocytic receptor and a strong negative regulator of T-cell proliferation and IL-2 production [111].

The proteins exclusively modulated in the urine of patients with digestive diseases that are overviewed at Fig. 2.

\section{Exploiting the urinary peptidome}

In order to explore the impact of diseases on urinary peptidome, differentially expressed peptides identified in several diseases were compared to a reference peptidome [112] consisting of 953 urinary peptides derived from 116 native proteins. To perform this analysis, only those peptides with known amino acids sequence were considered, corresponding to 95 differentially expressed peptides. All differentially expressed peptides were compared with diseaserelated DEPs and a set of 38 unique urinary peptides that did not result from the cleavage of other proteins present in the urine was found (Supplementary Table S8). To predict the main proteases involved in the generation of these peptides Proteasix [113], an 
open-source peptide-centric tool based on cleavage site specificity, was applied. Cathepsin L1 (CTSL1), kallikrein-2 (KLK2), kallikrein-6 (KLK6) and neprilysin (MME) were the proteases retrieved as the most probable ones involved in the modulation of urinary peptidome. Cathepsin L1 is a major excreted protein associated with adaptive immune response [114], exogenous peptide antigen processing and presentation via MHC [114], and extracellular matrix disassembly [115]. Kallikrein-2 is a glandular kallikrein that cleaves kininogen into Lys-bradykinin. This protease is primarily involved in extracellular matrix disassembly and organization, being also involved in small GTPase mediated signaling transduction [116]. Kallikrein-6 is responsible for the degradation of amyloid precursor protein, myelin basic protein, gelatin, casein, and extracellular matrix proteins, including fibronectin, laminin, vitronectin, and some collagens [117]. Neprilysin is an enzyme responsible for mediating the processing of sensory information by opioid peptides' degradation, and its upregulation might represent an organic attempt to cope the perception of pain that accompanies most diseases [118]. Taking into account the high number of urinary peptides involved in renal diseases and its repercussions in the cardiovascular system, the increased activity of neprilysin most likely reflects its involvement in the cleavage of angiotensin-1, angiotensin-2, angiotensin 1-9, and atrial natriuretic factor [119-121]. Moreover, neprilysin activity is remarkably upregulated during replicative senescence and intrinsic aging [122]. Increased activity of these four proteases is in accordance with the main biological processes modulated by human diseases in general. Despite unspecific, further studies on the activity of the peptidases responsible for urinary peptidome might provide useful insights into the molecular basis of human diseases.

\section{Conclusions and future perspectives}

The integrative analysis of urine proteome data highlighted the upregulation of inflammation in almost all diseases, though each disease seems to be associated with a specific inflammatory signature. Moreover, there is a set of proteins or peptides uniquely modulated by each disease and organic system involved, such as major prion protein in tuberculosis, peroxisomal acyl-coenzyme A oxidase 1 in bladder cancer, histone-lysine $\mathrm{N}$-methyltransferase 2D and collagen fragments in left ventricular diastolic dysfunction, immunoglobulin domain-containing protein 4 in pancreatitis, and P2X purinoceptor 4 in Kawasaki disease. For the enrichment of these proteins contributed exosomes, corroborating the importance of "liquid biopsies" in mediating cellular communication and possibly conveying pathogenicity-associated factors. Another interesting finding retrieved from the integrative analysis of proteome data is the abundance in the urine of proteins encoded by genes of fetal origin, revealing a deprogramming similar to the one observed in early stages of development. Data analysis also highlighted cathepsin L1, kallikrein-2, kallikrein-6 and neprilysin as the proteases most likely involved in the modulation of urinary peptidome, particularly in renal and cardiovascular diseases.

Future work should target the validation of urinary proteome/ peptidome data envisioning the development of multimarker panels to be implemented in the clinics for disease diagnosis and follow-up. The herein identified disease-specific proteins and peptides are expected to be the most valuable ones to integrate such panels.

\section{Acknowledgements}

This work was supported by the Portuguese Foundation for Science and Technology (FCT), European Union, QREN, FEDER and COMPETE for funding the iBiMED, UnIC, QOPNA research units (project UID/BIM/04501/2013, UID/IC/00051/2013, PEst-C/QUI/ UI0062/2013), COST action BM1305 and the Investigator Grant to RV (IF/00286/2015). This work was supported by the project DOCnet (NORTE-01-0145-FEDER-000003), supported by Norte Portugal Regional Operational Programme (NORTE 2020), under the PORTUGAL 2020 Partnership Agreement, through the European Regional Development Fund (ERDF), the project NETDIAMOND (POCI-01-0145-FEDER-016385), supported by European Structural and Investment Funds, Lisbon's Regional Operational Program 2020 and national funds from the PFCT, and the European Commission (FP7-Health-2010; MEDIA-261409).

\section{Appendix A. Supplementary data}

Supplementary data related to this article can be found at http:// dx.doi.org/10.1016/j.trac.2017.07.018.

\section{References}

[1] P. Findeisen, M. Neumaier, Mass spectrometry-based clinical proteomics profiling: current status and future directions, Expert Rev. Proteomics 6 (2009) 457-459, http://dx.doi.org/10.1586/epr.09.67.

[2] S.D. Patterson, R.H. Aebersold, Proteomics: the first decade and beyond, Nat. Genet. 33 (Suppl) (2003) 311-323, http://dx.doi.org/10.1038/ng1106.

[3] A.J. J. Atkinson, W.A. Colburn, V.G. DeGruttola, D.L. DeMets, G.J. Downing D.F. Hoth, J.A. Oates, C.C. Peck, R.T. Schooley, B.A. Spilker, J. Woodcock, S.L. Zeger, Biomarkers and surrogate endpoints: preferred definitions and conceptual framework, Clin. Pharmacol. Ther. 69 (2001) 89-95, http:// dx.doi.org/10.1067/mcp.2001.113989.

[4] M.P. Pavlou, E.P. Diamandis, I.M. Blasutig, The long journey of cancer biomarkers from the bench to the clinic, Clin. Chem. 59 (2013) 147-157, http:/ dx.doi.org/10.1373/clinchem.2012.184614.

[5] K. Kienzl-Wagner, J. Pratschke, G. Brandacher, Biomarker discovery in transplantation-proteomic adventure or mission impossible? Clin. Biochem. 46 (2013) 497-505, http://dx.doi.org/10.1016/j.clinbiochem.2012.10.010.

[6] M. Sedic, L.A. Gethings, J.P.C. Vissers, J.P. Shockcor, S. McDonald, O. Vasieva, M. Lemac, J.I. Langridge, D. Batinić, S.K. Pavelić, Label-free mass spectrometric profiling of urinary proteins and metabolites from paediatric idiopathic nephrotic syndrome, Biochem. Biophys. Res. Commun. 452 (2014) 21-26, http://dx.doi.org/10.1016/j.bbrc.2014.08.016.

[7] E.M. Damsgaard, A. Froland, O.D. Jorgensen, C.E. Morgensen, Prognostic value of urinary albumin excretion rate and other risk factors in elderly diabetic patients and non-diabetic control subjects surviving the first 5 years after assessment, Diabetologia 36 (1993) 1030-1036.

[8] S. Masson, R. Latini, V. Milani, L. Moretti, M.G. Rossi, E. Carbonieri, A. Frisinghelli, C. Minneci, M. Valisi, A.P. Maggioni, R. Marchioli, G. Tognoni, L. Tavazzi, Prevalence and prognostic value of elevated urinary albumin excretion in patients with chronic heart failure data from the GISSI-Heart failure trial, Circ. Hear. Fail. 3 (2010) 65-72, http://dx.doi.org/10.1161/ CIRCHEARTFAILURE.109.881805.

[9] H. Villacorta, V. Ferradaes Pde, E.T. Mesquita, A.C. Nobrega, Microalbuminuria is an independent prognostic marker in patients with chronic heart failure, Arq. Bras. Cardiol. 98 (2012) 62-69.

[10] I. De Boer, R. Katz, J. Cao, Cystatin C, albuminuria, and mortality among older adults with diabetes, Diabetes 32 (2009) 1833-1838, http://dx.doi.org/ 10.2337/dc09-0191.

[11] R.S. Lee, F. Monigatti, A.C. Briscoe, Z. Waldon, M.R. Freeman, H. Steen Optimizing sample handling for urinary proteomics, J. Proteome Res. 7 (2008) 4022-4030, http://dx.doi.org/10.1021/pr800301h.

[12] J.W. Froehlich, A.R. Vaezzadeh, M. Kirchner, A.C. Briscoe, O. Hofmann W. Hide, H. Steen, R.S. Lee, An in-depth comparison of the male pediatric and adult urinary proteomes, Biochim. Biophys. Acta 1844 (2014) 1044-1050 http://dx.doi.org/10.1016/j.bbapap.2013.05.008.

[13] M.A.E. Valente, K. Damman, P.H.J.M. Dunselman, H.L. Hillege, A.A. Voors, Urinary proteins in heart failure, Prog. Cardiovasc. Dis. 55 (2012) 44-55, http://dx.doi.org/10.1016/j.pcad.2012.04.009.

[14] V. Thongboonkerd, Urinary proteomics: towards biomarker discovery, diagnostics and prognostics, Mol Biosyst (2008) 810-815, http://dx.doi.org/ 10.1039/b802534g.

[15] I. Zubiri, F. Vivanco, G. Alvarez-Llamas, Proteomic analysis of urinary exosomes in cardiovascular and associated kidney diseases by two-dimensional electrophoresis and LC-MS/MS, Methods Mol. Biol. 1000 (2013) 209-220, http://dx.doi.org/10.1007/978-1-62703-405-0_16.

[16] K. Rejdak, S.M. Leary, A. Petzold, A.J. Thompson, D.H. Miller, G. Giovannoni, Urinary neopterin and nitric oxide metabolites as markers of interferon beta1a activity in primary progressive multiple sclerosis, Mult. Scler. 16 (2010) 1066-1072, http://dx.doi.org/10.1177/1352458510375100. 
[17] H. Mischak, Z.A. Massy, J. Jankowski, Proteomics in uremia and renal disease, Semin. Dial. 22 (2009) 409-416, http://dx.doi.org/10.1111/j.1525139X.2009.00591.x.

[18] H. Mischak, W. Kolch, M. Aivaliotis, D. Bouyssié, M. Court, H. Dihazi, G.H. Dihazi, J. Franke, J. Garin, A. Gonzalez de Peredo, A. Iphöfer, L. Jänsch, C. Lacroix, M. Makridakis, C. Masselon, J. Metzger, B. Monsarrat, M. Mrug, M. Norling, J. Novak, A. Pich, A. Pitt, E. Bongcam-Rudloff, J. Siwy, H. Suzuki, V. Thongboonkerd, L.-S. Wang, J. Zoidakis, P. Zürbig, J.P. Schanstra, A. Vlahou, Comprehensive human urine standards for comparability and standardization in clinical proteome analysis, Proteomics Clin. Appl. 4 (2010) 464-478, http://dx.doi.org/10.1002/prca.200900189.

[19] R. Roy, G. Louis, K.R. Loughlin, D. Wiederschain, S.M. Kilroy, C.C. Lamb, D. Zurakowski, M.A. Moses, Tumor-specific urinary matrix metalloproteinase fingerprinting: identification of high molecular weight urinary matrix metalloproteinase species, Clin. Cancer Res. 14 (2008) 6610-6617, http:/ dx.doi.org/10.1158/1078-0432.CCR-08-1136.

[20] N.C. Garbett, M.L. Merchant, C.W. Helm, A.B. Jenson, J.B. Klein, J.B. Chaires, Detection of cervical cancer biomarker patterns in blood plasma and urine by differential scanning calorimetry and mass spectrometry, PLoS One 9 (2014) e84710, http://dx.doi.org/10.1371/journal.pone.0084710.

[21] M. Frantzi, J. Metzger, R.E. Banks, H. Husi, J. Klein, M. Dakna, W. Mullen, J.J. Cartledge, J.P. Schanstra, K. Brand, M.A. Kuczyk, H. Mischak, A. Vlahou, D. Theodorescu, A.S. Merseburger, Discovery and validation of urinary biomarkers for detection of renal cell carcinoma, J. Proteomics 98 (2014) 44-58, http://dx.doi.org/10.1016/j.jprot.2013.12.010.

[22] J. Metzger, T. Kirsch, E. Schiffer, P. Ulger, E. Mentes, K. Brand, E.M. Weissinger, M. Haubitz, H. Mischak, S. Herget-Rosenthal, Urinary excretion of twenty peptides forms an early and accurate diagnostic pattern of acute kidney injury, Kidney Int. 78 (2010) 1252-1262, http://dx.doi.org/10.1038/ ki.2010.322.

[23] J. Ho, M. Lucy, O. Krokhin, K. Hayglass, E. Pascoe, G. Darroch, D. Rush, P. Nickerson, C. Rigatto, M. Reslerova, Mass spectrometry-based proteomic analysis of urine in acute kidney injury following cardiopulmonary bypass: a nested case-control study, Am. J. Kidney Dis. 53 (2009) 584-595, http:/ dx.doi.org/10.1053/j.ajkd.2008.10.037.

[24] L. Tsiatsiani, A.J.R. Heck, Proteomics beyond trypsin, FEBS J. 282 (2015) 2612-2626, http://dx.doi.org/10.1111/febs.13287.

[25] C. Eric Thomas, W. Sexton, K. Benson, R. Sutphen, J. Koomen, Urine collection and processing for protein biomarker discovery and quantification, Cancer Epidemiol. Biomarkers Prev. 19 (2010) 953-959, http://dx.doi.org/10.1158 1055-9965.EPI-10-0069.

[26] Y. Wang, J. Chen, L. Chen, P. Zheng, H.-B. Xu, J. Lu, J. Zhong, Y. Lei, C. Zhou, Q. Ma, Y. Li, P. Xie, Urinary peptidomics identifies potential biomarkers for major depressive disorder, Psychiatry Res. 217 (2014) 25-33, http:/ dx.doi.org/10.1016/j.psychres.2014.02.029.

[27] X.B. Ling, K. Lau, J.T. Kanegaye, Z. Pan, S. Peng, J. Ji, G. Liu, Y. Sato, T.T.S. Yu, J.C. Whitin, J. Schilling, J.C. Burns, H.J. Cohen, A diagnostic algorithm combining clinical and molecular data distinguishes Kawasaki disease from other febrile illnesses, BMC Med. 9 (2011) 130, http://dx.doi.org/10.1186/ 1741-7015-9-130.

[28] A. Kentsis, Y.Y. Lin, K. Kurek, M. Calicchio, Y.Y. Wang, F. Monigatti, F. Campagne, R. Lee, B. Horwitz, H. Steen, R. Bachur, Discovery and validation of urine markers of acute pediatric appendicitis using high-accuracy mass spectrometry, Ann. Emerg. Med. 55 (2010) 62-70.e4, http://dx.doi.org/ 10.1016/j.annemergmed.2009.04.020.

[29] L. Su, L. Cao, R. Zhou, Z. Jiang, K. Xiao, W. Kong, H. Wang, J. Deng, B. Wen, F. Tan, Y. Zhang, L. Xie, Identification of novel biomarkers for sepsis prognosis via urinary proteomic analysis using iTRAQ labeling and 2D-LC-MS/MS, PLoS One 8 (2013) e54237, http://dx.doi.org/10.1371/journal.pone.0054237.

[30] L. Su, R. Zhou, C. Liu, B. Wen, K. Xiao, W. Kong, F. Tan, Y. Huang, L. Cao, L. Xie, Urinary proteomics analysis for sepsis biomarkers with iTRAQ labeling and two-dimensional liquid chromatography-tandem mass spectrometry, J. Trauma Acute Care Surg. 74 (2013) 940-945, http://dx.doi.org/10.1097/ TA.0b013e31828272c5.

[31] G. Chen, Y. Zhang, X. Jin, L. Zhang, Y. Zhou, J. Niu, J. Chen, Y. Gu, Urinary proteomics analysis for renal injury in hypertensive disorders of pregnancy with iTRAQ labeling and LC-MS/MS, Proteomics Clin. Appl. 5 (2011) 300-310, http://dx.doi.org/10.1002/prca.201000100.

[32] T.K. Sigdel, A. Kaushal, M. Gritsenko, A.D. Norbeck, W.-J. Qian, W. Xiao, D.G. Camp, R.D. Smith, M.M. Sarwal, Shotgun proteomics identifies proteins specific for acute renal transplant rejection, Proteomics Clin. Appl. $4(2010)$ 32-47, http://dx.doi.org/10.1002/prca.200900124.

[33] C.I.A. Balog, O.A. Mayboroda, M. Wuhrer, C.H. Hokke, A.M. Deelder P.J. Hensbergen, Mass spectrometric identification of aberrantly glycosylated human apolipoprotein C-III peptides in urine from Schistosoma mansoniinfected individuals, Mol. Cell. Proteomics 9 (2010) 667-681, http:/ dx.doi.org/10.1074/mcp.M900537-MCP200.

[34] A.L. Petri, C. Høgdall, I.J. Christensen, A.H. Simonsen, D. T'Jampens, M.L. Hellmann, S.K. Kjaer, E.T. Fung, E. Høgdall, Sample handling for mass spectrometric proteomic investigations of human urine, Proteomics Clin. Appl. 2 (2008) 1184-1193, http://dx.doi.org/10.1002/prca.200780010.

[35] P. Olszowy, B. Buszewski, Urine sample preparation for proteomic analysis, J. Sep. Sci. (2014) 1-26, http://dx.doi.org/10.1002/jssc.201400331.

[36] M. Nawaz, G. Camussi, H. Valadi, I. Nazarenko, K. Ekstrom, X. Wang, S. Principe, N. Shah, N.M. Ashraf, F. Fatima, L. Neder, T. Kislinger, The emerging role of extracellular vesicles as biomarkers for urogenital cancers, Nat. Rev. Urol. 11 (2014) 688-701, http://dx.doi.org/10.1038/nrurol.2014.301.

[37] S. Filip, K. Vougas, J. Zoidakis, A. Latosinska, W. Mullen, G. Spasovski, H. Mischak, A. Vlahou, J. Jankowski, Comparison of depletion strategies for the enrichment of low-abundance proteins in urine, PLoS One 10 (2015) e0133773, http://dx.doi.org/10.1371/journal.pone.0133773.

[38] L. Sennels, M. Salek, L. Lomas, E. Boschetti, P.G. Righetti, J. Rappsilber, Proteomic analysis of human blood serum using peptide library beads, J. Proteome Res. 6 (2007) 4055-4062, http://dx.doi.org/10.1021/pr070339l.

[39] W.G. Fisher, J.E. Lucas, U.F. Mehdi, D.W. Qunibi, H.R. Garner, K.P. Rosenblatt, R.D. Toto, A method for isolation and identification of urinary biomarkers in patients with diabetic nephropathy, Proteomics - Clin. Appl. 5 (2011) 603-612, http://dx.doi.org/10.1002/prca.201000156.

[40] J. Adachi, C. Kumar, Y. Zhang, J.V. Olsen, M. Mann, The human urinary proteome contains more than 1500 proteins, including a large proportion of membrane proteins 7 (2006), http://dx.doi.org/10.1186/gb-2006-7-9-r80.

[41] L. Santucci, G. Candiano, A. Petretto, M. Bruschi, C. Lavarello, E. Inglese, P. Giorgio Righetti, G. Marco Ghiggeri, From hundreds to thousands: widening the normal human Urinome, Data $\mathrm{Br} 1$ (2014) 25-28, http:// dx.doi.org/10.1016/j.dib.2014.08.006.

[42] P.G.W. Gettins, Serpin structure, mechanism, and function, Chem. Rev. 102 (2002) 4751-4803, http://dx.doi.org/10.1021/cr010170+.

[43] A.J. Ridley, Rho family proteins: coordinating cell responses, Trends Cell Biol. 11 (2001) 471-477, http://dx.doi.org/10.1016/S0962-8924(01)02153-5.

[44] M. Symons, J. Settleman, Rho family GTPases: more than simple switches, Trends Cell Biol 10 (2000) 415-419, http://dx.doi.org/10.1016/S09628924(00)01832-8.

[45] S. Shalapour, M. Karin, Immunity, inflammation, and cancer: an eternal fight between good and evil, J. Clin. Invest. 125 (2015) 3347-3355, http:// dx.doi.org/10.1172/JCI80007.

[46] M.J. Smyth, G.P. Dunn, R.D. Schreiber, Cancer immunosurveillance and immunoediting: the roles of immunity in suppressing tumor development and shaping tumor immunogenicity, Adv. Immunol. 90 (2006) 1-50, http:/l dx.doi.org/10.1016/S0065-2776(06)90001-7.

[47] C. Bernardo, M.C. Cunha, J.H. Santos, J.M.C. Costa, P.J. Brindley, C. Lopes, F. Amado, R. Ferreira, R. Vitorino, L.L. Santos, Insight into the molecular basis of Schistosoma haematobium-induced bladder cancer through urine proteomics, Tumor Biol. (2016) 1-9, http://dx.doi.org/10.1007/s13277-016-4997-y.

[48] M. Dechant, W. Weisner, S. Berger, M. Peipp, T. Beyer, T. Schneider-Merck, J.J. Lammerts Van Bueren, W.K. Bleeker, P.W.H.I. Parren, J.G.J. Van De Winkel, T. Valerius, Complement-dependent tumor cell lysis triggered by combinations of epidermal growth factor receptor antibodies, Cancer Res 68 (2008) 4998-5003, http://dx.doi.org/10.1158/0008-5472.CAN-07-6226.

[49] M.M. Markiewski, R.A. DeAngelis, F. Benencia, S.K. Ricklin-Lichtsteiner, A. Koutoulaki, C. Gerard, G. Coukos, J.D. Lambris, Modulation of the antitumor immune response by complement, Nat. Immunol. 9 (2008) 1225-1235, http://dx.doi.org/10.1038/ni.1655.

[50] X. Wu, D. Spitzer, D. Mao, S.L. Peng, H. Molina, J.P. Atkinson, Membrane protein Crry maintains homeostasis of the complement system, J. Immunol. 181 (2008) 2732-2740, http://dx.doi.org/10.4049/jimmunol.181.4.2732.

[51] a P. Manderson, M.C. Pickering, M. Botto, M.J. Walport, C.R. Parish, Continual low-level activation of the classical complement pathway, J. Exp. Med. 194 (2001) 747-756, http://dx.doi.org/10.1084/jem.194.6.747.

[52] J.Charles A. Janeway, P. Travers, M. Walport, M.J. Shlomchik, Autoimmune Responses Are Directed against Self Antigens, 2001.

[53] C. Viret, F.S. Wong, C.A. Janeway, Designing and maintaining the mature TCR repertoire: the continuum of self-peptide:self-MHC complex recognition, Immunity 10 (1999) 559-568, http://dx.doi.org/10.1016/S1074-7613(00) 80055-2.

[54] Q. Ge, V.P. Rao, B.K. Cho, H.N. Eisen, J. Chen, Dependence of lymphopeniainduced $\mathrm{T}$ cell proliferation on the abundance of peptide/MHC epitopes and strength of their interaction with T cell receptors, Proc. Natl. Acad. Sci. U. S. A. 98 (2001) 1728-1733, http://dx.doi.org/10.1073/pnas.98.4.1728.

[55] J.J. Goronzy, C.M. Weyand, Thymic function and peripheral T-cell homeostasis in rheumatoid arthritis, Trends Immunol. 22 (2001) 251-255, http:// dx.doi.org/10.1016/S1471-4906(00)01841-X.

[56] S.S. Morse, N. Sakaguchi, S. Sakaguchi, Virus and autoimmunity: induction of autoimmune disease in mice by mouse T lymphotropic virus (MTLV) destroying CD4 + T cells, J. Immunol. 162 (1999) 5309-5316.

[57] R. Glas, L. Franksson, C. Une, M.L. Eloranta, C. Ohlén, A. Orn, K. Kärre, Recruitment and activation of natural killer (NK) cells in vivo determined by the target cell phenotype. An adaptive component of NK cell-mediated responses, J. Exp. Med. 191 (2000) 129-138.

[58] G. Ferlazzo, M. Pack, D. Thomas, C. Paludan, D. Schmid, T. Strowig, G. Bougras, W.A. Muller, L. Moretta, C. Münz, Distinct roles of IL-12 and IL-15 in human natural killer cell activation by dendritic cells from secondary lymphoid organs, Proc. Natl. Acad. Sci. U. S. A. 101 (2004) 16606-16611, http:// dx.doi.org/10.1073/pnas.0407522101.

[59] J. Ye, B. Zhu, Z.F. Fu, H. Chen, S. Cao, Immune evasion strategies of flaviviruses, Vaccine 31 (2013) 461-471, http://dx.doi.org/10.1016/j.vaccine.2012.11.015.

[60] L. Zhang, C.C. Wang, Inflammatory response of macrophages in infection, Hepatobiliary Pancreat. Dis. Int. 13 (2014) 138-152, http://dx.doi.org/ 10.1016/s1499-3872(14)60024-2.

[61] M.-S. Kim, S.M. Pinto, D. Getnet, R.S. Nirujogi, S.S. Manda, R. Chaerkady, A.K. Madugundu, D.S. Kelkar, R. Isserlin, S. Jain, J.K. Thomas, B. Muthusamy, 
P. Leal-Rojas, P. Kumar, N.A. Sahasrabuddhe, L. Balakrishnan, J. Advani, B. George, S. Renuse, L.D.N. Selvan, A.H. Patil, V. Nanjappa, A. Radhakrishnan, S. Prasad, T. Subbannayya, R. Raju, M. Kumar, S.K. Sreenivasamurthy, A. Marimuthu, G.J. Sathe, S. Chavan, K.K. Datta, Y. Subbannayya, A. Sahu, S.D. Yelamanchi, S. Jayaram, P. Rajagopalan, J. Sharma, K.R. Murthy, N. Syed, R. Goel, A.A. Khan, S. Ahmad, G. Dey, K. Mudgal, A. Chatterjee, T.-C. Huang, J. Zhong, X. Wu, P.G. Shaw, D. Freed, M.S. Zahari, K.K. Mukherjee, S.K.S. Shankar, A. Mahadevan, H. Lam, C.J. Mitchell, S.K.S. Shankar, P. Satishchandra, J.T. Schroeder, R. Sirdeshmukh, A. Maitra, S.D. Leach, C.G. Drake, M.K. Halushka, T.S.K. Prasad, R.H. Hruban, C.L. Kerr, G.D. Bader, C.A. Iacobuzio-Donahue, H. Gowda, A. Pandey, A draft map of the human proteome, Nature 509 (2014) 575-581, http://dx.doi.org/10.1038/nature13302.

[62] M. Monk, M. Boubelik, S. Lehnert, Temporal and regional changes in DNA methylation in the embryonic, extraembryonic and germ cell lineages during mouse embryo development, Development 99 (1987) 371-382.

[63] M. Monk, Of microbes, mice and man, Int. J. Dev. Biol. 45 (2001) 497-507.

[64] B. Foxman, The epidemiology of urinary tract infection, Nat. Rev. Urol. 7 (2010) 653-660, http://dx.doi.org/10.1038/nrurol.2010.190.

[65] R. Podschun, U. Ullmann, Klebsiella spp. as nosocomial pathogens: epidemiology, taxonomy, typing methods, and pathogenicity factors, Clin. Microbiol. Rev. 11 (1998) 589-603, doi: 0893-8512/98/\$04.00?0.

[66] I. Ofek, A. Mesika, M. Kalina, Y. Keisari, R. Podschun, H. Sahly, D. Chang, D. McGregor, E. Crouch, Surfactant protein D enhances phagocytosis and killing of unencapsulated phase variants of Klebsiella pneumoniae, Infect. Immun. 69 (2001) 24-33, http://dx.doi.org/10.1128/IAI.69.1.24-33.2001.

[67] G. Cortes, Molecular analysis of the contribution of the capsular polysaccharide and the lipopolysaccharide $O$ side chain to the virulence of Klebsiella pneumoniae in a murine model of pneumonia, Infect. Immun. 70 (2002) 2583-2590, http://dx.doi.org/10.1128/IAI.70.5.2583-2590.2002.

[68] R.G. Boot, G.H. Renkema, A. Strijland, A.J. Van Zonneveld, J.M.F.G. Aerts, Cloning of a cDNA encoding chitotriosidase, a human chitinase produced by macrophages, J. Biol. Chem. 270 (1995) 26252-26256, http://dx.doi.org/ 10.1074/jbc.270.44.26252.

[69] T.L. Leto, K.J. Lomax, B.D. Volpp, H. Nunoi, J.M. Sechler, W.M. Nauseef, R.A. Clark, J.I. Gallin, H.L. Malech, Cloning of a 67-kD neutrophil oxidase factor with similarity to a noncatalytic region of p60c-src, Science 248 (1990) 727-730.

[70] F.B. Wientjes, J.J. Hsuan, N.F. Totty, A.W. Segal, p40phox, a third cytosolic component of the activation complex of the NADPH oxidase to contain src homology 3 domains, Biochem. J. 296 (Pt 3) (1993) 557-561.

[71] J.R. Johnson, Virulence factors in Escherichia coli urinary tract infection, Clin. Microbiol. Rev. 4 (1991) 80-128, http://dx.doi.org/10.1128/CMR.4.1. 80.Updated.

[72] E.V. Sokurenko, V. Chesnokova, D.E. Dykhuizen, I. Ofek, X.R. Wu, K.A. Krogfelt, C. Struve, M.A. Schembri, D.L. Hasty, Pathogenic adaptation of Escherichia coli by natural variation of the FimH adhesin, Proc. Natl. Acad. Sci. U. S. A. 95 (1998) 8922-8926, http://dx.doi.org/10.1073/pnas.95.15.8922.

[73] T. Springall, N.S. Sheerin, K. Abe, V.M. Holers, H. Wan, S.H. Sacks, Epithelial secretion of $\mathrm{C} 3$ promotes colonization of the upper urinary tract by Escherichia coli, Nat. Med. 7 (2001) 801-806, http://dx.doi.org/10.1038/89923.

[74] S. Negrini, V.G. Gorgoulis, T.D. Halazonetis, Genomic instability-an evolving hallmark of cancer, Nat. Rev. Mol. Cell Biol. 11 (2010) 220-228, http:// dx.doi.org/10.1038/nrm2858.

[75] J. Plati, O. Bucur, R. Khosravi-Far, Apoptotic cell signaling in cancer progression and therapy, Integr. Biol. 3 (2011) 279-296, http://dx.doi.org/ 10.1039/c0ib00144a.

[76] Z. Werb, C.J. Sympson, C.M. Alexander, N. Thomasset, L.R. Lund, a MacAuley, J. Ashkenas, M.J. Bissell, Extracellular matrix remodeling and the regulation of epithelial-stromal interactions during differentiation and involution, Kidney Int. Suppl. 54 (1996) S68-S74.

[77] C. Scheel, R.A. Weinberg, Cancer stem cells and epithelial-mesenchymal transition: concepts and molecular links, Semin. Cancer Biol. 22 (2012) 396-403, http://dx.doi.org/10.1016/j.semcancer.2012.04.001.

[78] E.A. Turley, M. Veiseh, D.C. Radisky, M.J. Bissell, Mechanisms of disease: epithelial-mesenchymal transition-does cellular plasticity fuel neoplastic progression? Nat. Clin. Pract. Oncol. 5 (2008) 280-290, http://dx.doi.org/ 10.1038/ncponc1089.

[79] S.C. Sak, P. Harnden, C.F. Johnston, A.B. Paul, A.E. Kiltie, APE1 and XRCC1 protein expression levels predict cancer-specific survival following radical radiotherapy in bladder cancer, Clin. Cancer Res. 11 (2005) 6205-6211, http://dx.doi.org/10.1158/1078-0432.CCR-05-0045.

[80] C. Liu, Q. Yin, L. Li, Y.Z. Zhuang, X. Zu, Y. Wang, APE1 Asp148Glu gene polymorphism and bladder cancer risk: a meta-analysis, Mol. Biol. Rep. 40 (2013) 171-176, http://dx.doi.org/10.1007/s11033-012-2046-5.

[81] L. Wu, J.C. Zhao, J. Kim, H.-J. Jin, C.-Y. Wang, J. Yu, ERG is a critical regulator of Wnt/LEF1 signaling in prostate cancer, Cancer Res 73 (2013) 6068-6079, http://dx.doi.org/10.1158/0008-5472.CAN-13-0882.

[82] C. Ruiz, D.R. Holz, M. Oeggerli, S. Schneider, I.M. Gonzales, J.M. Kiefer, T. Zellweger, A. Bachmann, P.A. Koivisto, H.J. Helin, S. Mousses, M.T. Barrett, D.O. Azorsa, L. Bubendorf, Amplification and overexpression of vinculin are associated with increased tumour cell proliferation and progression in advanced prostate cancer, J. Pathol. 223 (2011) 543-552, http://dx.doi.org/ $10.1002 /$ path.2828.

[83] S. Omoigui, Cholesterol synthesis is the trigger and isoprenoid dependent interleukin-6 mediated inflammation is the common causative factor and therapeutic target for atherosclerotic vascular disease and age-related disorders including osteoporosis and type 2 diabetes, Med. Hypotheses 65 (2005) 559-569, http://dx.doi.org/10.1016/j.mehy.2005.03.012.

[84] C. Skerka, P.F. Zipfel, Complement factor $\mathrm{H}$ related proteins in immune dis eases, Vaccine 26 (2008), http://dx.doi.org/10.1016/j.vaccine.2008.11.021.

[85] D. Basavarajappa, M. Wan, A. Lukic, D. Steinhilber, B. Samuelsson, O. Rådmark, Roles of coactosin-like protein (CLP) and 5-lipoxygenase-activating protein (FLAP) in cellular leukotriene biosynthesis, Proc. Natl. Acad. Sci. 111 (2014) 11371-11376, http://dx.doi.org/10.1073/pnas.1410983111.

[86] N.J. Galjart, H. Morreau, R. Willemsen, N. Gillemans, E.J. Bonten, A. d'Azzo, Human lysosomal protective protein has cathepsin A-like activity distinct from its protective function, J. Biol. Chem. 266 (1991) 14754-14762.

[87] A.J. Soltys, F.C. Hay, A. Bond, J.S. Axford, M.G. Jones, I. Randen, K.M. Thompson, J.B. Natvig, The binding of synovial tissue-derived human monoclonal immunoglobulin $M$ rheumatoid factor to immunoglobulin $G$ preparations of differing galactose content, Scand. J. Immunol. 40 (1994) 135-143, http://dx.doi.org/10.1111/j.1365-3083.1994.tb03442.x.

[88] Y. Sancak, L. Bar-Peled, R. Zoncu, A.L. Markhard, S. Nada, D.M. Sabatini, Ragulator-rag complex targets mTORC1 to the lysosomal surface and is necessary for its activation by amino acids, Cell 141 (2010) 290-303, http:// dx.doi.org/10.1016/j.cell.2010.02.024.

[89] M. Prunotto, A. Farina, L. Lane, A. Pernin, J. Schifferli, D.F. Hochstrasser P. Lescuyer, S. Moll, Proteomic analysis of podocyte exosome-enriched fraction from normal human urine, J. Proteomics 82 (2013) 193-229, http://dx.doi.org/10.1016/j.jprot.2013.01.012.

[90] T.I. Odintsova, E.C. Müller, A.V. Ivanov, T.A. Egorov, R. Bienert, S.N. Vladimirov, S. Kostka, A. Otto, B. Wittmann-Liebold, G.G. Karpova, Characterization and analysis of posttranslational modifications of the human large cytoplasmic ribosomal subunit proteins by mass spectrometry and Edman sequencing, J. Protein Chem. 22 (2003) 249-258, http://dx.doi.org/ 10.1023/A:1025068419698.

[91] H.M. Mona, S.A. Sahar, S.M. Hend, A.-W.A. Nanees, Dyslipidemia in type 1 diabetes mellitus: relation to diabetes duration, glycemic control, body habitus, dietary intake and other epidemiological risk factors, Egypt. Pediatr. Assoc. Gaz. 63 (2015) 63-68, http://dx.doi.org/10.1016/ j.epag.2015.03.001.

[92] B. López, A. González, J. Díez, Circulating biomarkers of collagen metabolism in cardiac diseases, Circulation 121 (2010) 1645-1654, http://dx.doi.org/ 10.1161/CIRCULATIONAHA.109.912774.

[93] K. Jiao, H. Kulessa, K. Tompkins, Y. Zhou, L. Batts, H.S. Baldwin, B.L.M. Hogan, An essential role of Bmp4 in the atrioventricular septation of the mouse heart Genes Dev. 17 (2003) 2362-2367, http://dx.doi.org/10.1101/gad.1124803.

[94] R.Y. Kim, E.J. Robertson, M.J. Solloway, Bmp6 and Bmp7 are required for cushion formation and septation in the developing mouse heart, Dev. Biol. 235 (2001) 449-466, http://dx.doi.org/10.1006/dbio.2001.0284.

[95] J. Rivera-Feliciano, C.J. Tabin, Bmp2 instructs cardiac progenitors to form the heart-valve-inducing field, Dev. Biol. 295 (2006) 580-588, http://dx.doi.org/ 10.1016/j.ydbio.2006.03.043.

[96] N. El-Bizri, C. Guignabert, L. Wang, A. Cheng, K. Stankunas, C.-P. Chang, Y. Mishina, M. Rabinovitch, SM22alpha-targeted deletion of bone morphogenetic protein receptor $1 \mathrm{~A}$ in mice impairs cardiac and vascular development, and influences organogenesis, Development 135 (2008) 2981-2991, http://dx.doi.org/10.1242/dev.017863.

[97] T.A. Wynn, Cellular and molecular mechanisms of fibrosis, J. Pathol. 214 (2008) 199-210, http://dx.doi.org/10.1002/path.2277.

[98] G.L. Brower, J.D. Gardner, M.F. Forman, D.B. Murray, T. Voloshenyuk, S.P. Levick, J.S. Janicki, The relationship between myocardial extracellular matrix remodeling and ventricular function, Eur. J. Cardio Thoracic Surg. 30 (2006) 604-610, http://dx.doi.org/10.1016/j.ejcts.2006.07.006.

[99] R.N. Foley, A.M. Murray, S. Li, C.A. Herzog, A.M. McBean, P.W. Eggers, A.J. Collins, Chronic kidney disease and the risk for cardiovascular disease, renal replacement, and death in the United States Medicare population, 1998 to 1999, J. Am. Soc. Nephrol. 16 (2005) 489-495, http://dx.doi.org/10.1681/ ASN.2004030203.

[100] A. House, M. Haapio, J. Lassus, R. Bellomo, C. Ronco, Pharmacological management of cardiorenal syndromes, Int. J. Nephrol. 2011 (2011), 630809 http://dx.doi.org/10.4061/2011/630809.

[101] F. Genovese, P. Boor, M. Papasotiriou, D.J. Leeming, M.A. Karsdal, J. Floege, Turnover of type III collagen reflects disease severity and is associated with progression and microinflammation in patients with IgA nephropathy, Nephrol. Dial. Transpl. (2015), http://dx.doi.org/10.1093/ndt/gfv301.

[102] M. Yamagata, J.R. Sanes, Synaptic localization and function of Sidekick recognition molecules require MAGI scaffolding proteins, J. Neurosci. 30 (2010) 3579-3588, http://dx.doi.org/10.1523/JNEUROSCI.6319-09.2010.

[103] X. Wu, K. Hepner, S. Castelino-Prabhu, D. Do, M.B. Kaye, X.J. Yuan, J. Wood, C. Ross, C.L. Sawyers, Y.E. Whang, Evidence for regulation of the PTEN tumor suppressor by a membrane-localized multi-PDZ domain containing scaffold protein MAGI-2, Proc. Natl. Acad. Sci. U. S. A. 97 (2000) 4233-4238, http:// dx.doi.org/10.1073/pnas.97.8.4233.

[104] S. Babayeva, Y. Zilber, E. Torban, Planar cell polarity pathway regulates actin rearrangement, cell shape, motility, and nephrin distribution in podocytes, Am. J. Physiol. Ren. Physiol. 300 (2011) F549-F560, http://dx.doi.org/ 10.1152/ajprenal.00566.2009.

[105] M.S. Henning, P. Stiedl, D.S. Barry, R. McMahon, S.G. Morham, D. Walsh, M.H. Naghavi, PDZD8 is a novel moesin-interacting cytoskeletal regulatory 
protein that suppresses infection by herpes simplex virus type 1, Virology 415 (2011) 114-121, http://dx.doi.org/10.1016/j.virol.2011.04.006.

[106] N.S. Eyre, H.E. Drummer, M.R. Beard, The SR-BI partner PDZK1 facilitates hepatitis C virus entry, PLoS Pathog. 6 (2010), http://dx.doi.org/10.1371/ journal.ppat.1001130.

[107] C. Kranjec, L. Banks, A systematic analysis of human papillomavirus (HPV) E6 PDZ substrates identifies MAGI-1 as a major target of HPV type 16 (HPV-16) and HPV-18 whose loss accompanies disruption of tight junctions, J. Virol. 85 (2011) 1757-1764, http://dx.doi.org/10.1128/JVI.01756-10.

[108] B.A. Glaunsinger, S.S. Lee, M. Thomas, L. Banks, R. Javier, Interactions of the PDZ-protein MAGI-1 with adenovirus E4-ORF1 and high-risk papillomavirus E6 oncoproteins, Oncogene 19 (2000) 5270-5280, http://dx.doi.org/ 10.1038/sj.onc.1203906.

[109] M. Abrahamson, A.J. Barrett, G. Salvesen, A. Grubb, Isolation of six cysteine proteinase inhibitors from human urine. Their physicochemical and enzyme kinetic properties and concentrations in biological fluids, J. Biol. Chem. 261 (1986) 11282-11289, http://dx.doi.org/10.1002/elps.1150181516.

[110] D. Pende, C. Bottino, R. Castriconi, C. Cantoni, S. Marcenaro, P. Rivera, G.M. Spaggiari, A. Dondero, B. Carnemolla, N. Reymond, M.C. Mingari, M. Lopez, L. Moretta, A. Moretta, PVR (CD155) and Nectin-2 (CD112) as ligands of the human DNAM-1 (CD226) activating receptor: involvement in tumor cell lysis, Mol. Immunol. 42 (2005) 463-469, http://dx.doi.org/ 10.1016/j.molimm.2004.07.028.

[111] L. Vogt, N. Schmitz, M.O. Kurrer, M. Bauer, H.I. Hinton, S. Behnke, D. Gatto P. Sebbel, R.R. Beerli, I. Sonderegger, M. Kopf, P. Saudan, M.F. Bachmann, VSIG4, a B7 family-related protein, is a negative regulator of T cell activation, J. Clin. Invest. 116 (2006) 2817-2826, http://dx.doi.org/10.1172/JCI25673.

[112] J. Siwy, W. Mullen, I. Golovko, J. Franke, P. Zürbig, Human urinary peptide database for multiple disease biomarker discovery, Proteomics Clin. Appl. 5 (2011) 367-374, http://dx.doi.org/10.1002/prca.201000155.

[113] J. Klein, J. Eales, P. Zürbig, A. Vlahou, H. Mischak, R. Stevens, Proteasix: a tool for automated and large-scale prediction of proteases involved in naturally occurring peptide generation, Proteomics 13 (2013) 1077-1082, http:// dx.doi.org/10.1002/pmic.201200493.

[114] V. Zavasnik-Bergant, A. Schweiger, T. Bevec, R. Golouh, V. Turk, J. Kos, Inhibitory $\mathrm{p} 41$ isoform of invariant chain and its potential target enzymes cathepsins $\mathrm{L}$ and $\mathrm{H}$ in distinct populations of macrophages in human lymph nodes, Immunology 112 (2004) 378-385, http://dx.doi.org/10.1111/j.13652567.2004.01879.x

[115] J. Sage, E. Leblanc-Noblesse, C. Nizard, T. Sasaki, S. Schnebert, E. Perrier, R. Kurfurst, D. Brömme, G. Lalmanach, F. Lecaille, Cleavage of Nidogen-1 by cathepsin $\mathrm{S}$ impairs its binding to basement membrane partners, PLoS One 7 (2012) e43494, http://dx.doi.org/10.1371/journal.pone.0043494.

[116] A. Lundwall, V. Band, M. Blaber, J.A. Clements, Y. Courty, E.P. Diamandis, H. Fritz, H. Lilja, J. Malm, L.J. Maltais, A.Y. Olsson, C. Petraki, A. Scorilas, G. Sotiropoulou, U.-H. Stenman, C. Stephan, M. Talieri, G.M. Yousef, A comprehensive nomenclature for serine proteases with homology to tissue kallikreins, Biol. Chem. 387 (2006) 637-641, http://dx.doi.org/10.1515/ BC.2006.082.

[117] A Magklara, A.A Mellati, G.A. Wasney, S.P. Little, G. Sotiropoulou, G.W. Becker, E.P. Diamandis, Characterization of the enzymatic activity of human kallikrein 6: autoactivation, substrate specificity, and regulation by inhibitors, Biochem. Biophys. Res. Commun. 307 (2003) 948-955, http:// dx.doi.org/10.1016/S0006-291X(03)01271-3.

[118] A. Wisner, E. Dufour, M. Messaoudi, A. Nejdi, A. Marcel, M.-N. Ungeheuer, C. Rougeot, Human Opiorphin, a natural antinociceptive modulator of opioid-dependent pathways, Proc. Natl. Acad. Sci. U. S. A. 103 (2006) 17979-17984, http://dx.doi.org/10.1073/pnas.0605865103.

[119] G.I. Rice, D.A. Thomas, P.J. Grant, A.J. Turner, N.M. Hooper, Evaluation of angiotensin-converting enzyme (ACE), its homologue ACE2 and neprilysin in angiotensin peptide metabolism, Biochem. J. 383 (2004) 45-51, http:// dx.doi.org/10.1042/BJ20040634.

[120] T.G. Yandle, S.O. Brennan, E.A. Espiner, M.G. Nicholls, A.M. Richards, Endopeptidase-24.11 in human plasma degrades atrial natriuretic factor (ANF) to ANF(99-105/106-126), Peptides 10 (1989) 891-894, http://dx.doi.org/ 10.1016/0196-9781(89)90131-9.

[121] Y. Vanneste, A. Michel, R. Dimaline, T. Najdovski, M. Deschodt-Lanckman, Hydrolysis of alpha-human atrial natriuretic peptide in vitro by human kidney membranes and purified endopeptidase-24.11. Evidence for a novel cleavage site, Biochem. J. 254 (1988) 531-537.

[122] N. Morisaki, S. Moriwaki, Y, Sugiyama-Nakagiri, K. Haketa, Y Takema, G. Imokawa, Neprilysin is identical to skin fibroblast elastase: its role in skin aging and UV responses, J. Biol. Chem. 285 (2010) 39819-39827, http:// dx.doi.org/10.1074/jbc.M110.161547. 